\title{
Electrically Conductive Nanocomposites Polymer of Poly(Vinyl Alcohol)/Glutaraldehyde/Multiwalled Carbon Nanotubes: Preparation and Characterization
}

\author{
Fitri Khoerunnisa*, Hendrawan, Yaya Sonjaya, and Rizki Deli Hasanah \\ Department of Chemistry, Universitas Pendidikan Indonesia, \\ J. Dr. Setiabudi 229, Bandung 40154, Indonesia
}

Received July 17, 2017; Accepted January 26, 2018

\begin{abstract}
Electrically conductive nanocomposites polymer of poly(vinyl alcohol)/PVA, glutaraldehyde (GA) and multiwalled carbon nanotubes (MWCNT) has been successfully synthesized. The polymer nanocomposites were prepared by mixing PVA, GA (crosslinker), and MWCNT dispersion with an aid of ultrasonic homogenizer at $50{ }^{\circ} \mathrm{C}$. The content of MWCNT, in particular, was varied in order to determine the effect of MWCNT on electrical conductivity of polymer composites. The polymer mixture was casted into a disc to obtain a thin film. The electrical conductivity, surface morphology, and mechanical properties of the composites film were investigated by means of four probes method, FTIR spectroscopy, XRD, SEM, AFM, and tensile strength measurement, respectively. It was found that the optimum composition of PVA (10\%): GA (1\%): MWCNT (1\%) was 20:20:3 in volume ratio. The addition of MWCNT induced the electrically conductive network on polymer matrix where the electrical conductivity of nanocomposites film significantly increased up to $8.28 \times 10^{-2} \mathrm{~S} / \mathrm{sq}$ due to reduction of the contact resistance between conductive filler. Additionally, the mechanical strength of nanocomposites polymer were significantly increased as a result of MWCNT addition. Modification of morphological structure of composite film as indicated by FTIR spectra, XRD patterns, SEM and AFM images verified the effective MWCNT filler network in the polymer matrix.
\end{abstract}

Keywords: electrical conductivity; nanocomposites; poly(vinyl alcohol); multiwalled carbon nanotubes

\section{ABSTRAK}

Polimer konduktif berbasis nanokomposit poli(vinil alkohol)/PVA, glutaraldehid/GA, dan multiwall carbon nanotubes (MWCNT) telah berhasil disintesis. Polimer nanokomposit dibuat dengan mencampurkan larutan PVA dan agen crosslinker glutaraldehid (GA) dengan menggunakan homogeniser ultrasonik pada $50{ }^{\circ} \mathrm{C}$. Komposisi nanofiller MWCNTdivariasikan untuk mengetahui pengaruh penambahan MWCNT terhadap hantaran listrik polimer komposit PVA/GA. Campuran larutan polimer kemudian dicetak untuk memperoleh filim tipis. Hantaran listrik, morfologi permukaan, dan kekuatan mekanik dari film polimer komposit dikarakterisasi dengan menggunakan metode 4-probe, spektroskopi FTIR, XRD, SEM, AFM, dan pengukuran tensile strength secara berturut-turut. Hasil penelitian menunjukkan bahwa komposisi optimum PVA (10\%): GA (1\%): MWCNT (1\%) adalah 20:20:3 (perbandingan volume). Penambahan MWCNT menginduksi hantaran listrik dalam matrik polimer PVA/GA dimana hantaran listrik film nanokomposit meningkat secara signifikan sampai 8,28 $\times 10^{-2} \mathrm{~S} / \mathrm{sq}$ akibat pengurangan hambatan kontak diantara filler konduktif. Selain itu, kekuatan mekanik polimer komposit meningkat secara signifikan dan morfologi permukaan film mengalami modifikasi sebagai akibat penambahan MWCNT seperti ditunjukkan oleh spektra FTIR, pola XRD, foto SEM dan AFM, yang membuktikan pengisian filler MWCNT secara efektif dalam matrik polimer PVA/GA.

Kata Kunci: hantaran listrik; nanokomposit; poli(vinil alkohol); multiwall carbon nanotubes

\section{INTRODUCTION}

Recently, the need of conductive materials for electronic devices application i.e. smart window, light emitting diode, sensor, screen display, touch panel, and among others, is increasing in line with the massive development of the information and telecommunication

* Corresponding author.

Email address : fitri.khoerunnisa@gmail.com technologies [1-2]. Commonly, the raw materials for electronic device application were synthesized from organic/inorganic materials which have conductive properties. However, those materials have some disadvantages i.e. predominantly imported products, limited availability, high cost, non-renewable, and nondegradable. Hence, exploration and development of

DOI: $10.22146 /$ ijc. 26620

Fitri Khoerunnisa et al. 
alternative materials for device application should be more attractive to overcome those issues.

Polymer is one of the most abundant materials since it can be synthesized from various sources. Therefore, it is really favorable for many applications. The insulator property of polymers gives the limitation for its application in development and fabrication of electronic devices. On the other hand, the invention of conducting polymer by Shirakawa and Fleeger has been inspiring many researchers who work in polymer subject to improve and to modify any kind of polymers as conducting materials through adjustment of their electrical conductivity [3]. In general, polymers have unique properties such as flexibility, transparency, lightweight, and mechanical strength. Additionally, it offers advantages since its synthesis method is more divergent, simpler, and low cost, being promising for fabrication of conducting materials. Several natural polymers (poly-lactic acid, carrageenan, and chitosan) have been reported as raw material for that purpose [4].

Among the polymers, poly vinyl alcohol (PVA) is a very attractive material and has been used as the polymer host to form conductive polymer since it is stable both thermally and environmentally, nontoxic, water soluble, and has good film forming capacity. PVA has carbon chain backbone with hydroxyl groups attached where the $\mathrm{O}-\mathrm{H}$ bonds in the PVA assist the polymer complex formation [5]. PVA also has some good advantages such as high mechanical strength, excellent ionic conductivity, non-toxic, biocompatible, biodegradable and easy to prepare [6-8]. PVA has been used to fabricate environmentally friendly electrochemical devices such as lithium battery [9], electrochemical capacitor [10] and supercapacitor [11]. Tailoring electrical properties of PVA by insertion of additives i.e. metals, electrolytes, and nanoparticles have been reported [12-13]. In this connection, PVA, a good insulating material with low conductivity whose charge storage capability that can be markedly influenced by doping the suitable impurities has been chosen as the host polymer to obtain an enhanced conductivity.

On the other hand, nanocomposite materials with nanoscale fillers have emerged in the past decades as a promising novel class of materials, which take advantage of greatly increased specific interfacial area, higher achievable loads, controlled interfacial interactions, and higher overall compliance. The mismatch of the physical properties of the components becomes much less critical and the interfacial area between the filler and the matrix is maximized so that the interfacial strength can be much improved [14]. Currently, multifunctional nanocomposites with much improved mechanical performances are primarily fabricated by addition of pre-treated carbon nanotubes and nanofibers [15-16], inorganic nanoparticles [17-18], and metal nanostructures [17-19].

Carbon nanotubes (CNTs) have become one of the most actively studied materials because of their excellent properties, including low mass density, high flexibility, and remarkable mechanical, electrical, and thermal properties [20]. The extraordinary electrical conductivity [21] and very high aspect ratio (ca. 3001000 ) of CNT have made it one of the most promising conductive fillers for producing conductive polymer composite materials [22-23]. Carbon nanotubes (CNT) are nanoscale carbon materials having unique combination of mechanical, electrical, and thermal properties compared to other materials, offering many advantages for application in various fields. Besides, the distinctive characteristic of CNT i.e. superior surface area, high electrical conductivity, and low percolation of CNT when it is dispersed into polymer matrix, making CNT as one of excellent candidates of polymer filler [24]. The insertion of CNT into polymer matrix can ensure the improvement of electrical and mechanical properties of polymer.

The percolation theory is commonly used to describe the insulator-to-conductor transition in conductive filler-filled polymer composites. The electrical percolation threshold is the minimum filler concentration at which a conductive percolated pathway of the conductive filler is formed through the polymer matrix. Well dispersed CNT into polymer matrix is the main reason for the percolation threshold of the composites [25]. In this study, we prepared the composite of PVA and CNT for development of conductive film material.

\section{EXPERIMENTAL SECTION}

\section{Materials}

PVA with an average molecular weight (MW) of about 60000 and a degree of hydrolysis of $98-99 \%$, glutaraldehyde (GA), methanol, and sulphuric acid in pro analysis grade were purchased from Merck. Multiwalled carbon nanotubes (MWCNT) produced by chemical vapor deposition method was obtained from Wako Chemical, Japan. Compositions of polyvinyl alcohol, crosslinker (GA) [26], and multiwalled carbon nanotubes (MWCNT) used for the preparation of conductive film are shown in Table 1. The PVA and GA solutions were mixed at $50{ }^{\circ} \mathrm{C}$ for 2 min with an aid of ultrasonication. Hereafter, MWCNT dispersion was gradually added into solution mixture. The homogeneous mixture was then casted and dried to obtain thin film. 


\section{Instrumentation}

Instrumentation were used are Fourier transform infrared (FTIR) spectroscopy (Shimadzu), X-ray diffractometer (Rigaku Smartlab), atomic force microscopy (AFM, Agilent Technologies-5500SUI), scanning electron microscopy (SEM, JEOLJSM6335FS), tensile strength (Textechno-41066), and four probes (Chemical Analytech, Loresta-GP, MCP610).

\section{Procedure}

\section{Preparation of composite films}

Compositions of PVA, crosslinker (GA), and multiwalled carbon nanotubes (MWCNT) used for the preparation of conductive film are shown in Table 1. The PVA and GA solutions were mixed at $50{ }^{\circ} \mathrm{C}$ for $2 \mathrm{~min}$ with an aid of ultrasonication. Hereafter, MWCNT dispersion was gradually added into solution mixture. The homogeneous mixture was then casted and dried to obtain thin film.

\section{Characterization of composite films}

Fourier transform infrared (FTIR) spectroscopy (Shimadzu) measurement on thin film was carried out in the wavenumber region from 4000 to $400 \mathrm{~cm}^{-1}$. The FTIR were used for identifying the vibration regions of functional groups such as alkyl group, hydroxyl group, carboxyl, and other functionalities in the polymer matrix. The changes in FTIR characteristics of composites polymer induced by various amounts of CNT were also investigated. The X-ray diffraction studies were performed using an X-ray diffractometer (Rigaku Smartlab) with $2 \theta$ ranging from $5^{\circ}$ to $60^{\circ}$. The X-ray source is CuKa radiation with the wavelength $(\lambda=$ $1.54056 \AA$ ). . The atomic force microscopy (AFM, Agilent Technologies-5500SUI) and scanning electron microscopy (SEM, JEOL-JSM6335FS) measurement were conducted to obtain the information of morphology, rheology, and thickness of film surface. The mechanical strength and electrical conductivity of composite films were measured by means of Textechno-41066 and four probes (Chemical Analytech, Loresta-GP, MCP-610), respectively.

\section{RESULT AND DISCUSSION}

\section{Characteristics of Composite Films}

Fig. 1 represents the images of as-synthesized films of composite polymer with and without MWCNT insertion at different ratio. The MWCNT can homogenously dispersed in the polymeric matrix. The transparency of films slightly reduced by addition of
MWCNT, indicating well distributed of MWCNT into polymer matrix.

\section{Scanning electron microscopy images of composite films}

The scanning electron microscopy images (Fig. 2) demonstrates the flat-like surfaces and cross-sectional images of composites polymer films of PVA/GA $(a, b)$ and PVA/GA/MWCNT (c, d), respectively. The well dispersed MWCNT into polymer matrix of PVA/GA was

Table 1. Composition (volume) ratio of PVA, GA and MWCNT

\begin{tabular}{lccc}
\hline Sample & PVA (10\%) & GA (1\%) & MWCNT (1\%) \\
\hline$(1)$ & 20 & 20 & 2 \\
$(2)$ & 20 & 20 & 4 \\
$(3)$ & 20 & 20 & 5 \\
$(4)$ & 20 & 20 & 6 \\
$(5)$ & 20 & 20 & 8 \\
$(6)$ & 20 & 20 & 10 \\
$(7)$ & 20 & 20 & 12 \\
$(8)$ & 20 & 20 & 14 \\
\hline
\end{tabular}
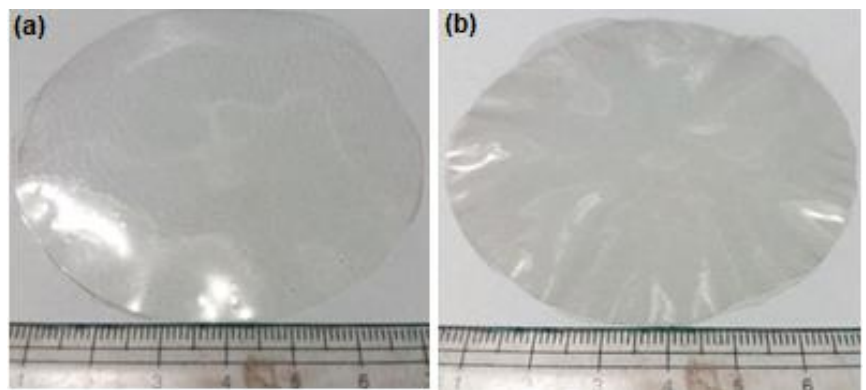

Fig 1. Composite polymer film images: (a) PVA/GA and (b) PVA/GA/MWCNT

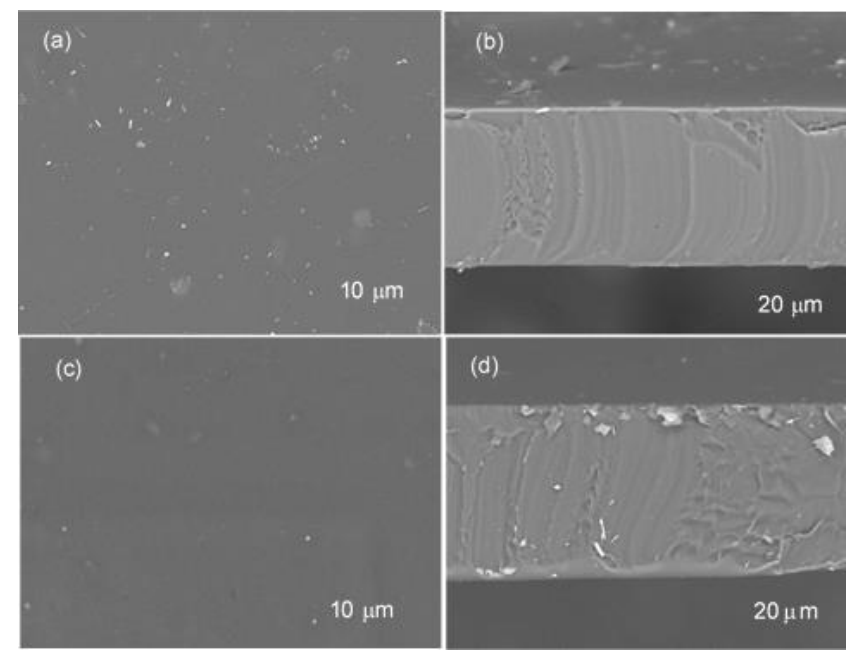

Fig 2. The SEM images of surface and cross-sectional of composite films of (a, b) PVA/GA and (c, d) PVA/GA/MWCNT, respectively 


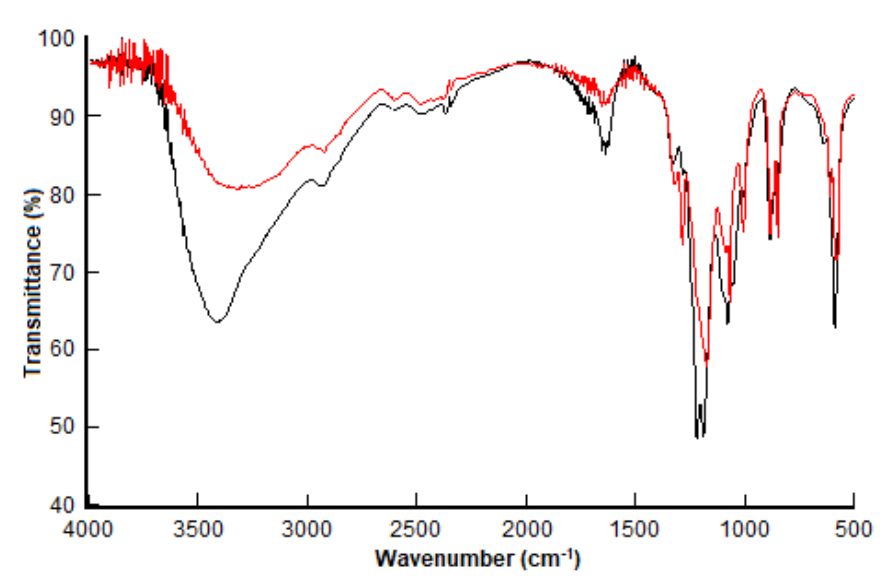

Fig 3. FTIR spectra of PVA/GA (black) and PVA/GA/MWCNT (red) films

indicated by the flat-like surface of composite film where the entangle bundle structure of MWCNT cannot be observed even though in the cross-section view.

This may lead to the percolation threshold of MWCNT filled polymer composite to induce insulatorconductor transition [15]. Additionally, the film thickness of polymer composites ranged from 60 to $70 \mu \mathrm{m}$ as indicated by the cross-sectional SEM images. The thin films should consisted of several layers. The insertion of MWCNT into PVA/GA slightly increases the film thickness, verifying the effective distribution of MWCNT filled polymer matrix due to its nanoscale [14]. The interaction of MWCNT and polymer matrix can be occurred through either van der Waals forces (physical interaction) or hydrogen bonding (chemical interaction).

\section{FTIR spectra of composite films}

A FTIR spectroscopy was used to identify the compound and to investigate the interactions in the polymer matrices. The FTIR spectra of PVA/GA and PVA/GA/MWCNT are shown in Fig. 3. The peak centered at $3416 \mathrm{~cm}^{-1}$ assigned to the stretching vibration of hydroxyl groups $(\mathrm{O}-\mathrm{H})$ of pure PVA [25,27] was shifted to $3327 \mathrm{~cm}^{-1}$, which indicates the specific interaction in the polymer systems. In addition to this, the $\mathrm{C}-\mathrm{H}$ stretching of $\mathrm{CH}_{2}$ which showed absorption at 2918 $\mathrm{cm}^{-1}$ in pure PVA [25-29] was shifted to $2924 \mathrm{~cm}^{-1}$. In particular the peak at $2900 \mathrm{~cm}^{-1}$ indicates the $\mathrm{C}-\mathrm{H}\left(\mathrm{sp}^{3}\right)$ stretching mode of aldehyde with the shoulder peak of alkyl chain, confirming the formation of acetal bridges due to interaction of PVA with GA crosslinker. The peak at 1655 and $1639 \mathrm{~cm}^{-1}$ was shifted to $1652 \mathrm{~cm}^{-1}$ that correspond to $\mathrm{C}=\mathrm{O}$ stretching of PVA. The vibration of $\mathrm{CH}_{2}$ group was found at $1333 \mathrm{~cm}^{-1}$ corresponding to C$\mathrm{H}$ wagging in pure PVA and it was shifted to lower wavenumbers. The $\mathrm{C}-\mathrm{C}$ stretching vibration of PVA appearing at 1285 and $1222 \mathrm{~cm}^{-1}$. The $\mathrm{C}-\mathrm{O}$ stretching occurred at $1080 \mathrm{~cm}^{-1}$ in PVA and it was shifted to 1088

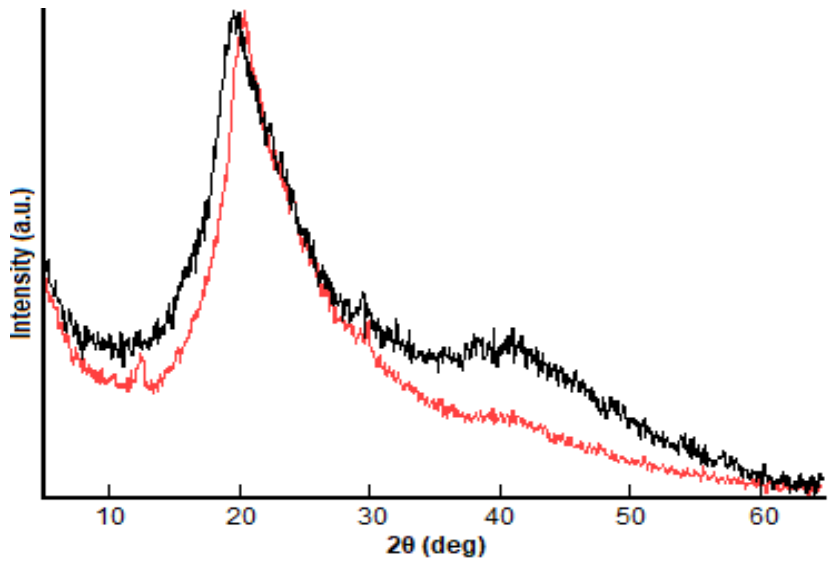

Fig 4. The X-ray diffraction patterns of PVA/GA (black) and PVA/GA/MWCNT (red) composite films

and $1070 \mathrm{~cm}^{-1}$. The vibration peak appearing at around $887 \mathrm{~cm}^{-1}$ assigned to $\mathrm{C}-\mathrm{H}$ rocking mode of PVA [27,29]. Hence, the insertion of MWCNT remarkably shifts the peak positions of wavenumber and increases \% peak transmittance of PVA/GA composites. These suggest the significant interaction between composite and MWCNT. The results clearly showed that the interaction between MWCNT and PVA in the polymer composites does not only arise from $\mathrm{O}-\mathrm{H}$ group but also from $\mathrm{C}-\mathrm{O}$ and $\mathrm{C}=\mathrm{O}$ groups, that predominantly occurred through intermolecular hydrogen bonding.

\section{$X$-ray diffraction patterns of composite films}

$X$-ray diffraction patterns are useful to determine structural and morphological transformation as well as crystallinity of composites films of PVA/GA with the MWCNT filler. Fig. 4 shows the XRD patterns $(\mu=$ $0.154056 \mathrm{~nm})$ of PVA/GA and PVA/GA/MWCNT composites films. The sharp crystalline reflections, with

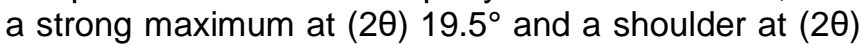
$19.9^{\circ}$, typical of the atactic crystallinity of PVA, are present [30]. The diffraction profile indicates that the sample is crystallized in the PVA structure characterized by chains in a trans-planar conformation, packed in a monoclinic unit cell with a) $7.81 \AA$, b) 2.52 $\AA$ (chain axis), and c) $5.51 \AA$. The other peaks position located at 22.26, 29.46, 37.92, and $40.94^{\circ}$ correspond to [200], [201], [110], and [211] lattices direction, respectively, that are characteristic for PVA [31]. The insertion of MWCNT into PVA/GA matrix induced the new peak and notably shifts and reduces the peak position and intensities confirming an effective insertion of MWCNT filler into composite polymer matrices. In particular the new peak at $12.32^{\circ}$ derived from small angle scattering interlayer bundle structure of MWCNT. The main peak shifted to $20.34^{\circ}$ and sharpen indicating the influence of lattice structure of 002 of MWCNT and a notable increase of crystallite degree of PVA due to 
MWCNT insertion, respectively. The other peak shifts were observed from 29.46 to $29.84^{\circ}$ indicating the modification of lattice direction of PVA [201] with MWCNT filler, meanwhile the reduction of peak intensity of [211] lattice direction was found due to MWCNT. Hence, this results evidence the transformation of morphological structure of PVA/GA composite film due to the interaction with MWCNT.

\section{Atomic force microscopy images of composite films}

Moreover, atomic force microscopy (AFM) images provide further information of morphological change of composite films through 3D profile of film surface in nanoscale (Fig. 5). In this case, the probe power $(<10$ $\mathrm{nm})$ and tip distance $(0.2-10 \mathrm{~nm})$ were selected as measurement condition of AFM. Fig. 5 shows the AFM images of PVA/GA and PVA/GA/MWCNT composite films, where the film surfaces, in general, are not completely flat but waving at several parts. Interestingly, the insertion of MWCNT into biopolymer matrix, the surface topography of film becomes more uneven due to MWCNT trapped inside the matrix. This results obviously in good agreement with other results explained above.

\section{Tensile strength of composite films}

Moreover, the insertion of MWCNT into composite matrix remarkably improves mechanical properties (tensile strength) of polymer composite film of PVA/GA. The effect of MWCNT addition into PVA/GA at different composition is summarized in Table 2. The measurement condition are as follow (sample dimension (2 mm x $30 \mathrm{~mm})$, staple distance $(5 \mathrm{~mm})$, and staple velocity $(5 \mathrm{~mm} / \mathrm{min})$. It can be inferred that the largest tensile strength parameter was obtained at MWCNT composition of $3 \mathrm{~mL}$ of total composites volume. Since MWCNT is already in nanoscale with high aspect ratio, it can facilitates the strengthened mechanical properties of
PVA/GA matrix as indicated by the increase both of maximum forces and elongation values. However, the larger amount of MWCNT composition in the film lead to the lowering tensile strength of PVA/GA due to possibility of the aggregation of MWCNT bundles.

\section{Electrical Conductivity of Composite Films}

The electrical conductivity of polymer composite films was measured by means of four probes method. The average value of electrical conductivity of PVA/GA films is about $10^{-8} \mathrm{~S} / \mathrm{cm}$ means this polymer film originally behaves insulator. The insertion of MWCNT significantly enhances the electrical conductivity of PVA/GA (Table 3) since MWCNT intrinsically has high electrical conductivity. The homogeneous dispersion of
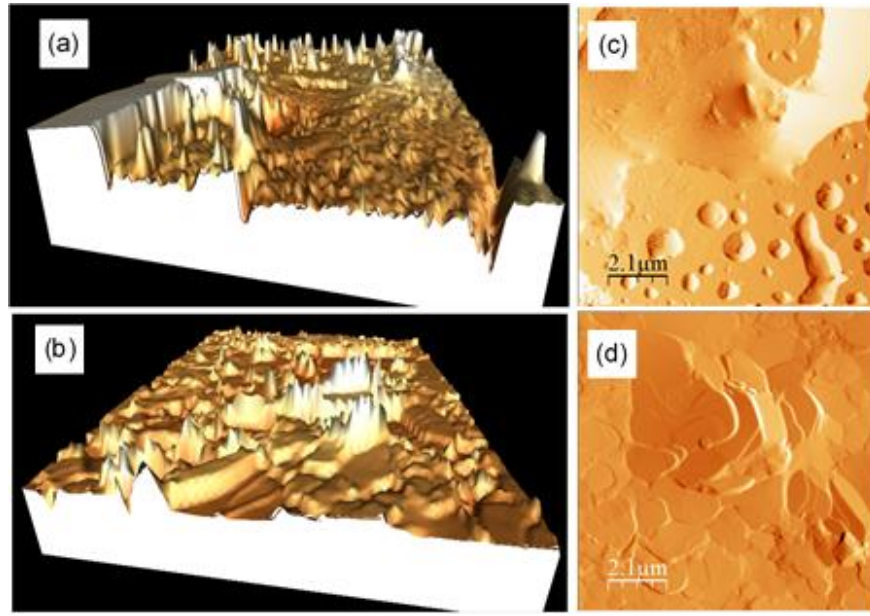

Fig 5. The AFM images of (a, c) PVA/GA and (b, d) PVA/GA/MWCNT composite films in $3 D$ and $2 D$, respectively

Table 2. Tensile strength parameter of composite films at various MWCNT compositions

\begin{tabular}{lccc}
\hline Samples & $\begin{array}{c}\text { Maximum } \\
\text { forces }(\mathrm{g})\end{array}$ & $\begin{array}{c}\text { Maximum } \\
\text { elongation }(\%)\end{array}$ & $\begin{array}{c}\text { Tensile strength } \\
\left(\mathrm{g} . \mathrm{cm}^{-2}\right)\end{array}$ \\
\hline PVA/GA & 318.3 & 339.9 & 300.2 \\
PVA/GA/MWCNT (2) & 455.5 & 418.4 & 569.5 \\
PVA/GA/MWCNT (3) & 555.3 & 494.6 & 797.2 \\
PVA/GA/MWCNT (5) & 354.9 & 391.7 & 372.3 \\
\hline
\end{tabular}

Table 3. Electrical conductivity values of composite films at various MWCNT compositions

\begin{tabular}{lcccc}
\hline Samples & \multicolumn{4}{c}{ Electrical conductivity $(\mathrm{S} / \mathrm{sq}) / \times 10^{-2}$} \\
\cline { 2 - 5 } & $\begin{array}{c}\text { Surfactant } \\
(0.1 \%)\end{array}$ & $\begin{array}{c}\text { Surfactant } \\
(0.2 \%)\end{array}$ & $\begin{array}{c}\text { Surfactant } \\
(0.5 \%)\end{array}$ & $\begin{array}{c}\text { Surfactant } \\
(1 \%)\end{array}$ \\
\hline PVA/GA & $10^{-6}$ & & & \\
PVA/GA/MWCNT(2) & 0.86 & 2.25 & 2.17 & 0.42 \\
PVA/GA/MWCNT (3) & 2.75 & 8.28 & 6.38 & 1.59 \\
PVA/GA/MWCNT (5) & 1.43 & 4.04 & 4.42 & 0.87 \\
PVA/GA/MWCNT (8) & 1.14 & 2.30 & 2.54 & 0.37 \\
\hline
\end{tabular}

Fitri Khoerunnisa et al. 
MWCNT into polymer matrix plays important role on controlling electrical conductivity of filler whereas MWCNT can effectively facilitate electron transport (tunneling) on polymer matrix even though at small composition ratio [32-33]. On the other hand, the well dispersed MWCNT can be kept by addition of surfactant. The larger amount of surfactant, however, decreases electrical conductivity of composite films because surfactant has insulator properties that can altered the contact between MWCNT/PVA/GA and electrical charges hence leads to discontinue of electrical conduction behavior [34]. Thus, the optimum amount of surfactant (PVA/GA/MWCNT) gives the highest electrical conductivity. The presence of impurities of MWCNT (amorphous carbon) as well as dispersant agent (surfactant) should take into account in the future study on preparation of conductive polymer films.

\section{CONCLUSION}

The conductive thin film based on composite of PVA/GA/MWCNT filler was successfully synthesized. The composite film thickness ranged from 60 to $70 \mu \mathrm{m}$ as indicated by the cross-sectional SEM images. The interaction between MWCNT and PVA in the composite polymer was not only arose from $\mathrm{O}-\mathrm{H}$ group but also from $\mathrm{C}-\mathrm{O}$ and $\mathrm{C}=\mathrm{O}$ groups, that predominantly occurred through intermolecular hydrogen bonding, as confirmed by FTIR spectra. The X-ray diffraction patterns indicated that the insertion of MWCNT into PVA/GA matrix induced the new peak and notably shifted and reduced the peak position and intensities, confirming the effective insertion of MWCNT filler into composite polymer. The insertion of MWCNT into composite matrix remarkably improved mechanical properties (tensile strength) and enhanced electrical conductivity (from $10^{-8}$ to $10^{-2} \mathrm{~S} / \mathrm{sq}$ ) of polymer composite film of PVA/GA. Further studies in term of temperature and thickness dependence on electrical conduction behavior of composite films are crucial to be intensively investigated.

\section{ACKNOWLEDGEMENT}

This work was supported by Ministry of Research, Technology and Higher Education of the Republic of Indonesia research grant 2017 (Hibah Penelitian Terapan-Unggulan Perguruan Tinggi). We thank to Prof Katsumi Kaneko (Center for Energy and Environmental science, Shinshu University, Japan) for kindly providing CNT samples and composite films characterizations, and to Prof. Young Gun Ko (Department of Advanced Material Engineering, Yeungnam University, Republic of Korea) for SEM observation.

\section{REFERENCES}

[1] Hu, B., Li, D., Manandharm, P., Fan, Q., Kasilingam, D., and Calvert, P., 2012, CNT/Conducting polymer composite conductors impart high flexibility to textile electroluminescent devices, J. Mater. Chem., 22 (4), 1598-1605.

[2] Snook, G.A., Kao, P., and Best, A.S., 2011, Conducting-polymer-based supercapacitor devices and electrodes, J. Power Sources, 196 (1), 1-12.

[3] Gangopadhyay, R., and De, A., 2000, Conducting polymer nanocomposites: A brief overview, Chem. Mater., 12 (3), 608-622.

[4] Kumar, B., Castro, M., and Feller J.F., 2012, Poly(lactic acid)-multi-wall carbon nanotube conductive biopolymer nanocomposite vapour sensors, Sens. Actuators, B, 161 (1), 621-628.

[5] Bhargav, P.B., Mohan, V.M., Sharma, A.K., and Rao, V.V.R.N., 2009, Investigations on electrical properties of (PVA: NaF) polymer electrolytes for electrochemical cell applications, Curr. Appl. Phys., 9 (1), 165-171.

[6] Jia, Y.T., Gong, J., Gu, X.H., Kim, H.Y., Dong, J., and Shen, X.Y., 2007, Fabrication and characterization of poly(vinyl alcohol)/chitosan blend nanofibers produced by electrospinning method, Carbohydr. Polym., 67 (3), 403-409.

[7] Rajendran, S., Sivakumar, M., and Subadevi, R., 2004, Li-ion conduction of plasticized PVA solid polymer electrolytes complexed with various lithium salts, Solid State Ionics, 167 (3-4), 335339.

[8] Dian, P.P., Erizal, E., and Basril, A., 2013, Polymeric biomaterials film based on poly(vinyl alcohol) and fish scale collagen by repetitive freeze-thaw cycles followed by gamma irradiation, Indones. J. Chem., 13 (3), 221-228.

[9] Chatterjee, J., Liu, T. Wang, B., and Zheng, J.P., 2010, Highly conductive PVA organogel electrolytes for applications of lithium batteries and electrochemical capacitors, Solid State Ionics, 181 (11-12), 531-535.

[10] Yu, H., Wu, J., Fan, L., Xu, K., Zhong, X., Lin, Y., and Lin, J., 2011, Improvement of the performance for quasi-solid-state supercapacitor by using PVA$\mathrm{KOH}-\mathrm{KI}$ polymer gel electrolyte, Electrochim. Acta, 56 (20), 6881-6886.

[11] Thostenson, E.T., Li, C.Y., and Chou, T.W., 2005, Nanocomposites in context, Compos. Sci. Technol., 65 (3-4), 491-516.

[12] Mittal, V., 2011, Surface Modification of Nanotube Filler, $1^{\text {st }}$ ed., Wiley-VCH, Weinheim, 94.

[13] Ajayan, P.M., Schadler, L.S., and Braun, P.V., 2006, Nanocomposite Science and Technology, Wiley-VCH, Weinheim, 80. 
[14] Ko, H., Jiang, C., Shulha, H., and Tsukruk, V.V., 2005, Carbon nanotube arrays encapsulated into freely suspended flexible films, Chem. Mater., 17 (10), 2490-2493.

[15] Cheng, Q., Wang, B., Zhang, C., and Liang, Z., 2010, Functionalized carbon-nanotube sheet/bismaleimide nanocomposites: mechanical and electrical performance beyond carbon-fiber composites, Small, 6 (6), 763-767.

[16] Mamedov, A.A., and Kotov, N.A., 2000, Freestanding layer-by-layer assembled films of magnetite nanoparticles, Langmuir, 16 (13), 55305533.

[17] Aroca, R.F, Goulet, P.J.G., dos Santos, D.S., AlvarezPuebla, R.A., and Oliveira, O.N., 2005, Silver nanowire layer-by-layer films as substrates for surface-enhanced Raman scattering, Anal. Chem., 77 (2), 378-382.

[18] Kovtyukhova, N.I., Martin B.R., Mbindyo, J.K.N., Smith, P.A., Razavi, B., Mayer, T.S., and Mallouk, T.E., 2001, Layer-by-layer assembly of rectifying junctions in and on metal nanowires, J. Phys. Chem. B, 105 (37), 8762-8769.

[19] Moniruzzaman, M., and Winey, K.I., 2006, Polymer nanocomposites containing carbon nanotubes, Macromolecules, 39 (16), 5194-5205.

[20] Meincke, O., Kaempfer, D., Weickmann, H., Friedrich, C., Vathauer, M., and Warth, H., 2004, Mechanical properties and electrical conductivity of carbon-nanotube filled polyamide- 6 and its blends with acrylonitrile/butadiene/styrene, Polymer, 45 (3), 739-748.

[21] Xu, Z., Zhang, Y., Wang, Z., Sun, N., and Li, H., 2011, Enhancement of electrical conductivity by changing phase morphology for composite consisting polylactide and poly( $\varepsilon$-caprolactone) filled with acid-oxidized multiwalled carbon nanotubes, ACS Appl. Mater. Interfaces, 3 (12), 4858-4864.

[22] Chu, C.C., White, K.L., Liu, P., Zhang, X., and Sue, H.J., 2012, Electrical conductivity and thermal stability of polypropylene containing well-dispersed multi-walled carbon nanotubes disentangled with exfoliated nanoplatelets, Carbon, 50 (12), 47114721.

[23] Long, Y.Z., Li, M.M., Gu, C., Wan, M., Duvail, J.L. Liu, Z., and Fan, Z., 2011, Recent advances in synthesis, physical properties and applications of conducting polymer nanotubes and nanofibers, Prog. Polym. Sci., 36 (10), 1415-1442.

[24] Peng, C., Zhang, S., Jewell, D., and Chen, G.Z., 2008, Carbon nanotube and conducting polymer composites for supercapacitors, Prog. Nat. Sci., 18 (7), 777-788.
[25] Balberg, I., Binenbaum, N., and Wagner, N., 1984, Percolation thresholds in the three-dimensional sticks system, Phys. Rev. Lett., 52 (17), 14651468.

[26] Santoso, U.T., Santosa, S.J., Siswanta, D., Rusdiarso, B., and Shimadzu, S., 2010, Characterization of sorbent produced through immobilization of humic acid on chitosan using glutaraldehyde as cross-linking agent and $\mathrm{Pb}(\mathrm{II})$ ion as active site protector, Indones. J. Chem., 10 (3), 301-309.

[27] Mansur, H.S., Sadahira, C.M., Souza, A.M., and Mansur, A.A.P., 2008, FTIR spectroscopy characterization of poly(vinyl alcohol) hydrogel with different hydrolysis degree and chemically crosslinked with glutaraldehyde, Mater. Sci. Eng., C, 28 (4), 539-548.

[28] Xue, B., Zhang, J., and Zhaou, T., 2015, Movingwindow two-dimensional correlation infrared spectroscopic study on the dissolution process of poly(vinyl alcohol), Anal. Bioanal. Chem., 407 (29), 8765-8771.

[29] Gupta, S., Prabha, C.R., and Murthy, C.N., 2016, Functionalized multi-walled carbon nanotubes/polyvinyl alcohol membrane coated glassy carbon electrode for efficient enzyme immobilization and glucose sensing, J. Environ. Chem. Eng., 4 (4A), 3734-3740.

[30] Malikov, E.Y., Muradov, M.B., Akperov, O.H., Eyvazoya, G.M., Puskas, R., Madarasz, D., Nagy, L., Kukovecz, A., and Konya, Z., 2014, Synthesis and characterization of polyvinyl alcohol based multiwalled carbon nanotube nanocomposites, Physica E, 61, 129-134.

[31] Ricciardi, R., Auriemma, F., Roda, C.D., and Laupetre, F., 2004, X-ray diffraction analysis of poly(vinyl alcohol) hydrogels, obtained by freezing and thawing techniques, Macromolecules, 37 (5), 1921-1927.

[32] Spitalsky, Z., Tasis, D., Papagelis, K., and Galiotis, C., 2010, Carbon nanotube-polymer composites: chemistry, processing, mechanical and electrical properties, Prog. Polym. Sci., 35 (3), 357-401.

[33] Jiang, Q., Wang, X., Zhu, Y., Hui, D., and Qiu, Y., 2014, Mechanical, electrical and thermal properties of aligned carbon nanotube/polyimide composites, Composites Part B, 56, 408-412.

[34] Tkalya, E.E., Ghislandi, M., de With, G., and Koning, C.E., 2012, The use of surfactants for dispersing carbon nanotubes and graphene to make conductive nanocomposites, Curr. Opin. Colloid Interface Sci., 17 (4), 225-232. 